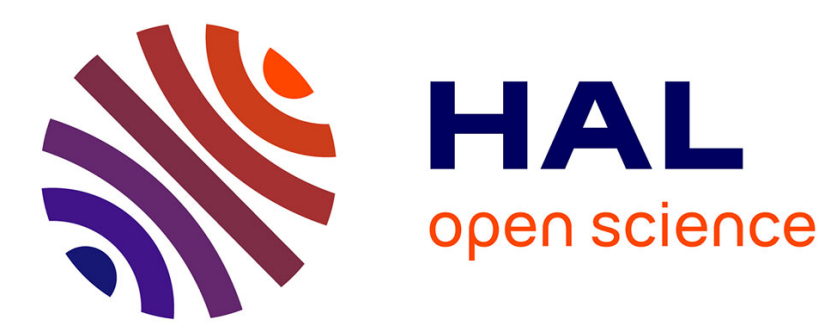

\title{
FOR THE LOVE OF A FISH: A LACANIAN READING OF MARGARET ATWOOD'S SURFACING
}

\author{
Jennifer Murray
}

\section{- To cite this version:}

Jennifer Murray. FOR THE LOVE OF A FISH: A LACANIAN READING OF MARGARET ATWOOD'S SURFACING . LIT: Literature Interpretation Theory, 2015, 26 (1), pp. 1-21. 10.1080/10436928.2015.996276 . hal-01119170v2

\section{HAL Id: hal-01119170 \\ https://hal.science/hal-01119170v2}

Submitted on 18 Apr 2018

HAL is a multi-disciplinary open access archive for the deposit and dissemination of scientific research documents, whether they are published or not. The documents may come from teaching and research institutions in France or abroad, or from public or private research centers.
L'archive ouverte pluridisciplinaire HAL, est destinée au dépôt et à la diffusion de documents scientifiques de niveau recherche, publiés ou non, émanant des établissements d'enseignement et de recherche français ou étrangers, des laboratoires publics ou privés. 
This is an Author's Original Manuscript of an article published by Taylor \& Francis in LIT: Literature Interpretation Theory on 13 Feb 2015, available online: https://tandfonline.com/doi/full/10.1080/10436928.2015.996276

FOR THE LOVE OF A FISH:

A LACANiAn REAding OF MARgaRet AtWoOd's SURFACING

JENNIFER MURRAY

Who is it, exactly, you have needed all these years to forgive?

"Up," Margaret Atwood, Morning in the Burned House, 1995

\section{The Quest. Again?}

In Margaret Atwood, Coral Ann Howells refers to Surfacing as the novel that bears the signature of Atwood's Canadian identity (20). Indeed, within the framework of the 1970s Canadian culture it belongs to, the novel captures the crucial social, political, environmental debates of the period, framing them within the question of what was specifically Canadian about Canadians; the only definitive answer to which was that the question suddenly mattered to them. One could go further however, and by focusing on the question of subjectivity, argue that Surfacing is Atwood's signature text tout court, or even her signerature, where Lacan's use of rature ("Lituraterre" 17) ${ }^{1}$ refers to the way in which the speakingbeing is marked by the signifier which metaphorically digs its groove, etching into the subject in formation, the unique letter of her singular being (Lacan, "Lituraterre" 17). Ginette Michaux formulates it in 
the following terms:

Man, the language-being, lives under the universal hold of the signifier which rains down upon the world, but from this downpour results a singular gullying effect that Lacan compares to a marking (rature) in which the singularity of the subject may be read. (11)

This is not the whole story of our subjectivity, but it tells us something of the way in which our first contact with language blazes a particular trail in our being, giving it direction. Unquestionably, as a narrative that deals with a female character's personal past, imaginatively drawing on the structure and details of the author's own history, Surfacing carries the author's 'mark' and constitutes a very personal myth of origins focusing on questions of life, death, language, family and how to be in society. It is, in the briefest of terms, the story of a woman who sets off on a journey to the remote island of her childhood in northern Quebec in search of her missing father, and who, in the process, recovers the repressed memory of the abortion she underwent in the course of a relationship with a married man. The search for knowledge of the father's whereabouts becomes, as the quest structure requires, a journey towards self-knowledge, involving a return to origins.

This has led critics to pursue the enigma of origins by way of the character's regression: regression to the past in search of self-rehabilitation, identity or redemption, (Howells 25-29; Hutcheon 144), to primal nature, in search of authentic values (Davey 79; Hutcheon 145; Tolan 38-42; Woodcock 112), ${ }^{2}$ to the mother, in search of a feminine gift or continuum (Barzilai, "Quest Romance" 166); in each case the end point seems to raise a new series of questions: what does it mean to look for one's past? What does one do with it if one finds it? Why should simply recognizing the 'truth' of one's past offer solace or cure for selfalienation? In each of these propositions, the past is concentrated in a central figure that is 
posited as that towards which or whom the narrator feels guilt: the aborted child, nature in some general sense, the values of her parents; furthermore, it is suggested that the narrator's 'redemption' or self-forgiveness is a matter of symbolically repairing the fault towards this internalized 'Other,' of which some particular 'other' is the representative. To this extent, analysis of the regression stops at the level of symbolic relationships, and its causes can then easily be subsumed within an available social discourse. Indeed, if the cause of guilt in the woman could be accounted for in terms of her relationship to someone or something outside of herself, then it would be transposable onto other, similar intersubjective situations: in other words, one could make a moral of it to illustrate some cause: feminism, anti-feminism, primitivism, ecology, nationalism, etc.

My view is that a more fundamental form of guilt is at stake here, one which is only transposable as a structure: what the heroine of Surfacing is 'guilty' of is the abdication of her autonomy as a subject, or, in other terms, the betrayal of her desire. In the Lacanian perspective, desire has a special place in subjectivity; it emerges from our encounter with the lack in the Other, initially in the form of gaps, understatements, contradictions in the parental discourse. Desire is the effect of the child's attempt to answer the enigma: "He is saying this to me, but what does he want?"(Lacan, Four 214). The first aspect therefore is a dialectical questioning of the lack in the Other, a burgeoning awareness, born of language, that the Other wants. This opening up of a space of lack-in-being generates desire, the desire to fill the lack, and Lacan's object $a$ is the name of the two faces of this desire-producing lack: it refers simultaneously to the original lack in being which the signifying cut produces, and to the array of 'things' that the subject will turn her desire to in an attempt to recover an imaginary fullness of being. It is in this sense that the object $a$ is the object-cause of desire: as lack, it is 
cause; as that which veils the lack, it is object. Because there is no object that can efface the originary lack which marks the subject's entry into the signifying world, and no final answer to the question of what the Other wants, desire is endlessly metonymic; it is always "desire in the second degree, desire of desire" (Lacan, Ethics 17). Thus the child cannot answer the question of the Other's desire directly, but answers with its own lack, the lack opened up by the equivocation of the signifier and veiled by fantasy. The intimate structure of our subjectivity is therefore invisible to us, a lack woven into the signifying mesh and which is masked by our striving for some wholeness that language gets in the way of attaining: "Language divides us into fragments, I wanted to be whole" (187), says the heroine of Surfacing. That this 'whole' is a myth - since - "[t]here is no whole. Nothing is whole" (Lacan in Fink, Clinical 129) - is irrelevant to desire's quest: the protagonist pursues her myth of wholeness, in the hope of recovering "the other half" (138) of herself. What she does recover, I will argue, is not some mythical 'half,' either in herself or, even less, in a partner, but the signifier of her desire, which is nothing other than the signifier of lack, the condition for the metonymy of feeling; after all, the burning question the narrator asks herself throughout the novel is not whether or not she 'did the right thing' but why she doesn't feel anything. It is therefore as a myth of the origins of desire that I should like to read this text.

\section{Guilt}

From the first lines of the novel, the unnamed narrator's discourse constructs a depleted, diseased, corrupted world: the words "twisting," "dying," "disease," "burnt out," "grey," "pallid as fisheyes," "bleary," (3), attach themselves to everything she contemplates: the road, trees, food, or roadside advertising signs. As she travels with her recently acquired friends (7) 
on a journey into her symbolic and geographical past of her childhood, she expects to feel something. Approaching her destination - the island in the north of Quebec where she grew up and where her father has gone missing — she is, "waiting for the nostalgia to hit [...] but nothing happens" (17). The absence of feeling which gives its tone to the narration is therefore present from the beginning of the novel and will manifest itself in the heroine's lack of emotional response, involvement, or attachment to people and events around her. For example, when she refers to sex with her nominal boyfriend Joe, she avoids all connotative language, such as 'making love' and refers to their physical encounter as just one example of 'it', 'it' being something that she finds "best when you don't know them"; feeling is evacuated and the experience is evaluated in terms of "what works" (83). The perfunctory aspect of the sexual act involving this clearly replaceable partner (the North American expressions 'the average Joe' or 'any old Joe' come to mind here) is communicated in the following colourless statement: "When we're finished and after we rest I get up and dress and go out to prepare the fish" (83). No expression of exchange, dialogue with, or desire for, her partner is offered: sex is simply part of the day's routine.

This impression of being emotionally absent from one's own life corresponds to the narrator's later declared self-perception: “I realized I didn't feel much of anything, I hadn't for a long time. Perhaps I'd been like that all my life, just as some babies are born deaf or without a sense of touch; but if that was true I wouldn't have noticed the absence" (134). This 'realization' of a gap between the self she once was, in a period when she had been "all right" (138), or at least "alive" (136) and her present-time "frozen" state (136) will precipitate her desire to know. This experience of self-division is manifest when she is called upon to express her feelings: when Joe asks "Do you love me" she is caught between his expectations and her 
inability to even engage with the question in those terms: “'I want to,' I said. 'I do in a way.' I hunted through my brain for any emotion that would coincide with what I said. I did want to, but it was like thinking God should exist and not being able to believe" (135). She comes to envy Joe for his ability to experience feeling: "His face contorted, it was pain: I envied him" (136) On this journey to find out what happened to her missing father, the veritable object of the quest has now come into focus: "it was no longer [my father's] death but my own that concerned me" (136). The woman is at this point, in the position of a subject whose need to know is becoming greater than her anxiety at finding out.

What is she afraid of finding out? That this draining-away of life, this emotional numbness, is the price she is paying for her sense of guilt. But why should she feel such pervasive guilt, "a sickening complicity, sticky as glue, blood on my hands," (167) and why should guilt produce this generalized absence of feeling?

In the Lacanian perspective, there is only one thing one can feel guilty about: the betrayal of one's desire: "I propose that from an analytical point of view, the only thing of which one can be guilty is of having given ground relative to one's desire" (Lacan, Ethics 392). We noted above that desire emerges as a response to the recognition of lack in the Other, but the response is not arbitrary; it has to do with the signifiers of the parental discourse; it is related to the place that the parents have made for the child in their world, through their language, and the way in which the child is marked by these signifiers. Desire is, in Lacanian terms, equivalent to the grounding law of one's singularity. Yet, if guilt arises from our failure to be true to the singularity of our being, the law of our desire, this does not necessarily tell us how to live. Indeed, the problem is that the foundation of the law of our being belongs to the murky past of our subjective formation. As sound as the advice was, Hamlet's course of action was 
not necessarily illuminated by Polonius' injunction: "This above all, to thine own self be true." To be true to the self, in Lacanian terms, entails fidelity to the grounding signifiers of one's law of desire and this is the injunction that Surfacing proclaims through its writing, in spite of the narrator's deflection onto the theme of victimisation when she transforms Polonius's words into: "This above all: to refuse to be a victim" (249) at the novel's close.

So how can we be true to a desire that founds our being in the world, which is unique to each and of which we have no positive knowledge? On the one hand, by listening to our guilt, since "our only consciousness of the (internal) law is our consciousness of our transgression of it. Our guilt is all we know of the law" (Copjec 143). If the positive content of the law is obscure to each subject who bears it, Lacan situates an essential parameter in the fact that "[this] law is in the first place always the acceptance of something that began to be articulated before [the subject] in previous generations, and which is strictly speaking Atè.” The signifiers of our subjectivity therefore have 'something to do with' our family history, its defining limits, its fate, its excesses, its lack.

If we are attentive to the signifiers that "swarm" (Lacan, On Feminine Sexuality 181) around the guilt experienced by the protagonist in Surfacing, we see that there is something to which the family values were attached. The only 'law' remembered from childhood - one which gives direction to her entire discourse on 'wholeness'- is the injunction not to kill needlessly: "Killing was wrong, we had been told that: only enemies and food could be killed" (167). This reference to a parental moral commandment is first evoked in relation to a childhood memory, but is reactivated later in the novel in the context of David's tormenting of Anna:

I wanted to run down to the dock and stop them, fighting was wrong, we weren't 
allowed to, if we did both sides got punished as in a real war. So we battled in secret, undeclared, and after a while I no longer fought back because I never won. (173, my emphasis)

The metonymic slippage here between "them" (David and Anna) and "we" (a reference to herself and her brother) finds the parental commandment, "fighting was wrong," interposed between them, so that the parental signifiers retain their force in the present-day of the narrator's feelings. This is not to say that contradictions in the parental decisions or choices could not be perceived, such as when, in spite of her prohibition of fighting, the mother "had to back down" (89) in order for her son to be able to defend himself at school. It is rather that the exceptions to the rule do not undermine its force and simply reveal the lack at the centre of all our attempts to answer the enigma of the other's desire. For the heroine of Surfacing, the prohibition of "fighting," of "cruelty" and "killing" form the cluster of parental expectations, they name the desire that she wishes to answer in return through an affirmation of life.

What remains obscure is the point at which small compromises, negotiations and 'backing down' become self-betrayal. In all cases, there is a debt to be paid, and guilt is the sign of the increase of the debt. Diffuse and often without any clear object, the guilt that the subject experiences can be formulated as a response to the question "Have you acted in conformity with the desire that is in you?" (Lacan, Ethics 386).

If analysis has a meaning, desire is nothing other than that which supports us in a particular destiny, and that destiny demands insistently that the debt be paid, and desire keeps coming back, keeps returning, and situates us once again in a given track, the track of something that is specifically our business. (Lacan, Ethics 393)

Guilt, then, would seem to be the price we pay for getting 'off track'. 


\section{The Loss of Desire}

It is "on this road again" (3) that the narrator finds herself, in the first line of the novel. This is the 'given track' of her subjectivity, and it will be marked with a certain number of determining signifiers. Consider, for example, the abundance of words related to 'nature': from a list of twenty-two words that are recurrent in the novel, ${ }^{3}$ six nouns occur more than one hundred times: lake (121 times), water (114), tree (114), fish (104), hand (146), and eye (103). The materiality of nature and the organs of the body that enable the senses of sight and touch constitute a strong nexus of signifiers linking the heroine to the natural world, especially in its most liquid form, since, taken together, 'water' and 'lake' account for 235 occurrences. 'Tree' offers the vertical, solid counterpoint to the aquatic elements, the hand and the eye reach out from the body towards this natural world, and the fish, well, what is the function of the fish? For the sake of hypothesis, let's say that the fish is the primary moving signifier of the protagonist's desire. We will see that, as it is used in the novel, the fish is a mediator, a sublimated indeterminate signifier capable of becoming the space of projection of all the forms of fantasy necessary for the narrator to play out the tale of her desire, its loss and its tentative recovery. In order not to compromise on her desire, she must not betray the fish.

And yet, that is precisely what she does. She takes her companions out fishing, an activity with which she has never had any ethical problem in the past, seeing it as a survival activity, and therefore outside the definition of human cruelty. Nevertheless, she finds herself, on this occasion, reluctant to assume the job of killing the fish on behalf of her survival-incompetent friends.

"Here," I say, "hit it back of the eyes." I reach him the sheathed knife, I'd rather not kill it myself.

David swipes at it, misses; Anna cover her eyes and says "Ugh. Ugh.” It flops 
towards me and I step down on it with my foot and grab the knife and whack it quickly with the knife handle, crushing the skull, and it trembles stiffly all over, that's done it.

"What is it?" David asks, amazed by what he's caught but proud too. They are all laughing, joyful with victory and relief, like the newsreels of parades at the end of the war, and that makes me glad. Their voices bounce off the cliff. ${ }^{4}$

"Walleye," I say, "Pickerel. We'll have it for breakfast."

It's a good size. I pick it up, fingers hooked under the gills and holding firmly, they can bite and jerk loose even when they're dead. I put it on the bracken fronds and rinse my hand and the knife. One of its eyes is bulging out and I feel a little sick, it's because I've killed something, made it dead; but I know that's irrational, killing certain things is all right, food and enemies, fish and mosquitoes. (79-80)

We see the protagonist at odds with herself here; on the one hand, rationally, she refers to a general rule: for the needs of human nourishment, killing fish is 'all right'; her parents only prohibited 'needless' killing. Moreover, one of the rare expressions of sentiment in the novel comes here: she is "glad" to have enabled a moment of communal satisfaction at the feat accomplished. Yet, on another level, she experiences unease: she'd "rather not kill it" herself, and once she has done it, she sees the fish's "eye bulging out", an accusing eye that makes her feel "a little sick [...] because I've killed something, made it dead." (80). ${ }^{5}$ The accusing eye of the dead fish becomes linked to a series of screen images protecting the woman from the memory of her submission to her previous lover's pressure for her to have an abortion. When this memory later becomes conscious, it does so in a form which assimilates the aborted foetus with science lab specimens: "it was in a bottle curled up, staring out at me like a cat pickled" but also with the fish: "it had huge jelly eyes and fins instead of hands, fish gills, I couldn't let it out, it was dead already, it had drowned in air" (183). Like the fish flopping about in the boat, 'it' - the aborted foetus - is figured as having "drowned in air," and the signifiers 'fins' and 'fish gills' to describe the foetus make the associations between the abortion and the killing of the fish clear. Some critics, such as Frank Davey (79), have taken this regret over an 
abortion as evidence, especially in the context of 1970s women's rights battles for the right to safe abortions, of a conservative political stance. This seems to miss the point. The abortion here is regretted because it is an act which engages the subjectivity of the protagonist: "Whatever it is, part of myself or a separate creature, I killed it. It wasn't a child but it could have been one, I didn't allow it" (183). Although one might indeed be tempted to extrapolate from this "I didn't allow it" to a generalized implicit "one should always allow a foetus to become a child', and thereby construct Surfacing as a conservative text in relation to the prochoice feminism of the same epoch, the narrative never makes this move: it is "the specific business" of the narrator. ${ }^{6}$ In fact, in spite of her recognition that the abortion was done on the insistence of someone else, she takes full responsibility for it: "I killed it," "I didn't allow it."

Why did the narrator compromise on her desire, the coherence of her subjectivity? If desire is always desire of the Other, it is by extension, also the desire for the return of desire from a specific 'other': in her relationship to her former lover, she remembers, "I worshipped him" (190). From this adulated representative of the Other comes the injunction to betray herself: "He said I should do it, he made me do it; he talked about it as though it was legal, ${ }^{7}$ simple, like getting a wart removed" (185). ${ }^{8}$ In the conflict between two directions of desire, that of remaining faithful to her path of being, and the concomitant and contradictory desire to please a specific other, she chose the latter in a context in which something fundamental, the founding injunction 'Killing is wrong,' was at stake for her. In so doing, she cut herself off from desire itself and wound up in "the quagmire of libidinal limbo, a nether world which is desireless and in which the [subject] drifts aimlessly" (Fink, Clinical 52). severed from the other affects, for "without desire, you cannot have jealousy, anger, disappointment, narcissistic wounding, or enjoyment" (Bailly 110). 
Why is that so? Why should the effect of compromising on one's desire be so farreaching? The concept of the objet a may enlighten us here. We noted earlier that in the process of becoming a subject, something is gained - access to the world of symbolization and something is lost: what we retroactively construct as fullness, wholeness, intimations of immortality. This 'something lost' leaves a left-over, what Lacan calls the lamella, or in other words, "the libido, qua pure life instinct, that is to say, immortal life, or irrepressible life" (Lacan, Four 198) of which the object $a$ is the representative. The object $a$ is in this sense the representative both of what is lost and of what remains, a shadowy leftover that persists in the transition from animal instinct to speakingbeing jouissance, that form of satisfaction that must compose with language and its constraints. As the 'something left over' in the transition from the real (the order that designates that which always falls outside of, and indeed, constitutes, the limits of human symbolization) into the symbolic, the objet $a$ is the stuff of fantasy; it has one foot in the drives, and another in the signifier and the two are bound together in a way which is singular for each speakingbeing; it is understood as the object-cause of desire, giving direction to the drives by designating and transforming the objects to which it reaches out.

In Surfacing, since the memory of her abortion remains inaccessible to the heroine for two-thirds of the narrative, she is at pains to understand why she has so little feeling in relation to others, why her desire has gone flat. She studies the seemingly nonsensical drawings left in the cabin by her father, drawings which gradually take on the role of signs to be interpreted to find the way back to her desire, and, on second examination, she notices: "There was a gap, something not accounted for, something left over" (132, italics added). This statement illustrates the very structure of the objet a which emerges from a "gap," the gap in our being which is the result of our alienation from a mythical wholeness upon our 
entry into the order of language; furthermore, it is an object, but can nonetheless never be "accounted for": it is a surplus enjoyment (le plus-de-jouir), always outside of the accountancy either of the biological or the cultural. Moreover, the movement of the phrase, from the negative "something not accounted for," to the positive "something left over" takes us in the direction of that very "something more" (than the thing-in-itself), the something "In you more than you" (Lacan, Four 268) that the objet a designates.

A few pages further on, looking at some photographs, left not by her father, but pasted into an album by her mother, she notes: "I was in most of the pictures, shut in behind the paper; or not me but the missing part of me" (137). This "missing part" is analogous to the part that was sacrificed, the objet $a$, in the betrayal of her desire.

This missing something then becomes overdetermined by imagery that situates the loss of the self in the metaphor of amputation:

[...] I'd allowed myself to be cut in two. Woman sawn apart in a wooden crate, wearing a bathing suit, smiling, a trick done with mirrors, I read it in a comic book; only with me there had been an accident and I came apart. The other half, the one locked away, was the only one that could live; I was the wrong half, detached, terminal. I was nothing but a head, or no, something minor like a severed thumb; numb. At school they used to play a joke, they would bring little boxes with cotton wool in them and a hole cut in the bottom; they would poke their finger through the hole and pretend it was a dead finger. (138)

The metonymy of this image of self-division, leaving nothing of the protagonist but a detachable nub of flesh, something "dead," captures the mutilating effect of self-betrayal": indeed the comment Lacan makes on the destructiveness of the renouncement of one's desire is almost chilling: "Something is played out in betrayal if one tolerates it ... Once one has crossed that boundary where I combined in a single term contempt for the other and for oneself, there is no way back. It might be possible to do some repair work, but not to undo it" 
(Lacan, Ethics 394-95).

Amongst the images that Surfacing associates with this self-mutilation are: the foetus, the fish, the detached dead finger, all of which can all be seen as metonymic displacements of the signifier 'phallus.' In Lacanian theory, the phallus is the signifier of desire, and of lack. ${ }^{10}$ In the inaugural moment of desire, the mythical moment of the perception of lack in the Other, and specifically, the revelation of the "castration of the maternal Other" (Braunstein 110) to the extent that she is revealed as desiring something, and therefore as not sufficient unto herself, the phallus comes to signify 'what the mother desires', and by association, orients desire towards the desire of the Other. If the question of whether another signifier could potentially stand in the place of the phallus as primary signifier remains open, theoretically speaking (Fink, Lacanian Subject102), in Surfacing, the primary signifier of desire remains figuratively proximate to its masculine representatives: indeed, the heroine is looking for her father, having given in to the male lover who she 'worshipped', and desiring the 'child' who is figured in the novel as masculine, as a "fur god with tail and horns" (235). ${ }^{11} 12$

To desire the phallus, as signifier of (the (m)Other's) desire, as the desire of the other made one's own, the narrator desires no specific thing but to recover her "desirousness" 13 associated with but metonymically distanced from any one representative. It is the phallic fish that allows us to follow this movement.

\section{Reparation}

The conceptualization of a missing part of herself, leads the woman to yearn for reparation, so that reparation for a 'fault' and restoration to her own desire become part of the same movement. The fish will be invoked once again to symbolize what is at stake for the heroine: 
she is being given another chance. On the second fishing trip, when David catches another fish, he expects her to finish it off, as she had done the first time: “'Hey,' David was saying, 'kill it for me"" (153). But this time, in the name of the fish, perceived now as a "neckless headbody," in other words, a creature without division - "the fish is whole" - she thinks, "I couldn't any more, I had no right to" (153) and replies "You do it." This refusal, this small gesture is a crucial one that re-orientates the woman in her relationship to her subjectivity. Moreover, it is the first in a series of decisions that will progressively detach her from the grip of the superego - that Freudian instance rewritten by Lacan as the obscene enjoying underside of the neutral law, the other face of the primal dead father - which takes the form in the novel of David's 'be a good sport' discourse of domination and humiliation: re-situated in a direction of inner coherence, the woman will no longer be the self-contradictory servant of this alienating discourse.

What then is the nature of the act that allows for this reorientation of the self?

The Lacanian concept of the ethical act has grandiose connotations, and is the stuff of heroes, and yet, is accessible: Lacan notes, "In each of us the path of the hero is traced, and it is precisely as an ordinary man that one follows it to the end" (Lacan, Ethics 393). The path of the hero is traced in each of us, in the sense that the signifier has marked in each speaking subject, the groove of his or her desire. The ethical act is the extreme tenacity of holding on to one's desire, even at the cost of one's place within the symbolic order. It involves "radical metamorphosis," “a wild tearing away from [one]self" (Copjec 114) which may result, as in the much-cited case of Antigone, "in destroying [the] community in the name of what is impossible in it" (Copjec 41). More simply put, it is an absolute refusal, at all costs, to respond to the desire of an other, where that other challenges the more fundamental (Other) 
desire that defines one's very subjectivity.

Is all of this a bit overstated for the woman of the Canadian wilderness, out on a fishing trip? Yes and no. Yes, in the sense that her refusal to 'carry on as usual, play the game, be a good sport' does not require radical self-destruction. And no, not at all, in the sense that within the perspective of her own subjectivity and its history, she refuses, absolutely, to participate in what she has identified as the structure of the problem: "there were only two things you could be, a winner or a loser" (87). This is just one manifestation of the disenchanted perspective the woman has on the world; she expresses disappointment that it doesn't, that they, men, don't measure up: whereas she affirms that "men ought to be superior" (141) she notices that they are not, or at least, not in the ways that are important to her. Of her former lover, she notes "He was neither of the things I believed, he was only a normal man, middle-aged, second-rate, selfish and kind in the average proportions; but I was not prepared for the average, its needless cruelties and lies" (246). She carries on without interruption to situate her brother's 'choice': "My brother saw the danger early. To immerse oneself, join in the war, or to be destroyed" and finishes on another 'ought': "Though there ought to be other choices" (246). Finally, of her father, she judges that "His job was wrong, he was really a surveyor, he learned the trees, naming and counting them so the others could level and excavate." In keeping with the hysterical structure which dominates the character's textual subjectivity, ${ }^{14}$ she 'makes the man', in other words, she redeems the dead father by affirming, "He must know that by now" (242).

Nonetheless, she does not absolve herself, as a woman, from accountability, and the recognition of her responsibility in the abandonment of her desire, enacted through the refusal to kill the fish, allows the woman renewed access to emotion: "feeling was seeping back into 
me" (140). But this is only the beginning for her. After refusing to kill the fish, she requires of herself, in order to re-enter the territory of desire, to symbolically undo the abortion by returning to and repeating the moment of conception in a will to procreate taken as far as possible out of the symbolization of civilisation, now seen as corrupt. It is through an imaginary leap into animal copulation with the unwitting Joe that the narrator accedes to forgiveness:

Teeth grinding, he's holding back, he wants it to be like the city, baroque scrollwork, intricate as a computer, but I'm impatient, pleasure is redundant, the animals don't have pleasure. I guide him into me, it's the right season, I hurry. He trembles and then I can feel my lost child surfacing within me, forgiving me, rising from the lake where it has been prisoned for so long, its eyes and teeth phosphorescent; the two halves clasp, interlocking like fingers, it buds, it sends out fronds. (209)

In what is, from one perspective, blatant instrumentalization of Joe, the woman once again accomplishes the sexual act in terms that are unconcerned with the subjective relationship with her partner. ${ }^{15}$ She is concerned only with re-enacting the 'primal scene' that led to both her pregnancy and her abortion, and in so doing, attempts to exculpate herself. Indeed, in this passage, she imaginatively arrives at self-forgiveness, where the "lost child surfacing within [her]" is metaphorically her lost self, the childhood of her being, the mythical pre-fallen self that she feels divided from, as was divined at the beginning of the story by Anna, reading her palm: "You had a good childhood but then there's this funny break" (5). It is a paradox that the symbolic moment of inception that will potentially restore her to her desire is also the one that determines her need to withdraw from the symbolic order, from society.

This is the beginning of the entanglement in which Atwood's novel gets caught up: in order to escape the language of patriarchal civilisation figured in the above quotation as history and technology ("baroque scrollwork," "computer") with Joe as its generic 
representative, and so as to make place for the feminine (seen here as organic — 'buds' and 'fronds') the heroine takes up the stance of a radical refusal of language. Envisioning her future child, she vows, "I will never teach it any words" (209). Only outside of language does she imagine that she will be able to approach that part of herself which she values, which is related to the supposed integrity of the organic world. Yet outside of language, there is no human existence, where human is defined as the speakingbeing, that being which is marked, even branded by language. Here, then, is the vicious circle the story struggles with: language, the language of Western culture as experienced by the protagonist in the society of her period is a language determined by the desire to dominate. It is the excess of patriarchy, where the paternal function of the law has lost its mediating force, and is itself overrun by unbridled jouissance; where the ability to kill, not for survival, but for the pure pleasure of domination, is a measure of the subject's value: one must strive to be the strongest, and therefore, destroy the competition. For the woman in Surfacing, there is no place within the order of language for her desiring self, insofar as it is anchored to a refusal of cruelty — "If you look like them and talk like them and think like them then you are them, $[\ldots]$ you speak their language, a language is everything you do" (165) — and she therefore attempts to step out of it.

The hypothesis she explores is that outside of language, one might exist, as an incorrupt animal-spirit: she attempts to 'enter' this other world in three stages, firstly by 'freeing' the other creatures whose captivity she has colluded in; secondly, by escaping from her group of friends, thereby avoiding a return to civilization, and finally by symbolically destroying all traces of civilization on the island. These different steps are the coherent consequences of the refusal to kill the fish, and taken together, constitute an ethical act since they resituate her on the path of her desire. 


\section{Ethical Madness}

The freeing of her 'fellow captives' is simultaneously an act of destruction: she exposes David's film, 'Random Samples', a collection of anecdotal images of domination gathered in the course of their journey to the sunlight. The film culminates in the humiliating image of Anna, forced by David to strip herself naked. The protagonist releases the captured images, in spite of the cautionary words of Anna:

I unzip the bag with the camera equipment and lift out the cannisters of film.

"What're you doing?" Anna says, listlessly however.

I unwind the film, standing full in the sun, and let it spiral into the lake. "You better not do that," Anna says, "they'll kill you." But she doesn't interfere, she doesn't call them.

When I've unravelled the reels I open the back of the camera. The film coils onto the sand under the water, weighted down by its containers; the invisible captured images are swimming away into the lake like tadpoles, Joe and David beside their defeated log, axemen, arms folded, Anna with no clothes on jumping off the end of the dock, finger up, hundreds of tiny naked Annas no longer bottled and shelved.

I study her to see if her release has made any difference, but the green eyes regard me unaltered from the enamel face. "They'll get you," she says, doleful as a prophet. "You shouldn't have done it." (214-15)

Anna's role in the scene is essential: she is emblematic of the captured victim, and yet does not want to participate in the symbolic act of freeing herself: she is entirely caught within the discourse of the superegoic Other, represented by David, which designates her place as that of colluding victim. ${ }^{16}$ Resistance, to her, seems more dangerous than submission, the danger being the loss of her place as object of desire and jouissance for David, her loss of the place as his chosen woman. It is therefore in spite of Anna that Anna's liberated images go spawning freedom into the lake, metonymically enacting the protagonist's need to undo all forms of unjust captivity and cruelty that she has been a party to, for all the times she "had been there 
and watched without saying No or doing anything to stop it: one of the silent guarded faces in the crowd" (167).

For the protagonist, by destroying David's filmic trophy, she has committed an act that will sever her from the community she belongs to- her group of friends; she therefore jumps into a canoe and distances herself from them, and in so doing, recognizes the mark of her unconscious desire: “The direction is clear. I see I've been planning this, for how long I can't tell" (216). The danger, however, is that beyond oneself, detached from community and in a state of rejection of the symbolic law, lies psychosis where "the difference between signification and reference falls away" (Zizek x). ${ }^{17}$ Stated differently, words lose their attachment to each other, lose their metaphorical stability of effect, and return as unpredictable and menacing, or, in the poetic use made of them here, as free-floating and malleable. The woman regresses to this state of pseudo-animality, a form of imagined pre-subjectivization:

The animals have no need for speech, why talk when you are a word I lean against a tree, I am a tree leaning

I am not an animal or a tree, I am the thing in which the trees and animals move and grow, I am a place (236)

In the performative metamorphosis at work here, enacting a return to oneness with the organic world, (to the $\mathrm{s} / \mathrm{m} / \mathrm{Other}$ ) where no lack exists, where the very signifier of lack and incompleteness is foreclosed, there is no subjectivity possible. And yet, the morbid force of the stasis of the image is masked, or perhaps undermined, by the fact that it is a lovely language trick performed by the narrator.

Indeed, the enunciation of the process of disinvestment of language is, in this instance, a sophisticated language construction, a poetic invention, a sublimation. Passing through the 
confusion of the self with signifiers of animal and plant life, and then receding to an indefinable 'place-being' this metamorphosis into a new non-human form effaces cause and effect, and careers off into a metonymic process of self-naming, subtracting the subject from the symbolic order, from the Name-of-the-Father which inscribes the subject in history.

Unsurprisingly, the woman does not linger in this limbo: "I have to get up, I get up. Through the ground, break surface, I'm standing now" (236). Assuming the human position, she is no longer animal, tree or place, but in a position to assume her subjectivity. The definitive return to the earth is excluded, but the contact with it, and the breaking away is also a form of rebirth: in the same way that the imaginary forgiveness of the child is selfforgiveness, and the re-conception of the child is self-conception, here we see the woman imaginatively de-subjectifying and then re-subjectifying herself, bringing herself into the world. It is therefore quite natural that she should then encounter her parents: they appear as ghostlike figures, visible to the protagonist but unseeing: firstly her mother, "[she] looks at me, past me, as though she knows something is there but she can't quite see it" (176). The non-regard of the mother may be read as indifference, but its function, on the contrary, could be understood as the transmission to her daughter of the knowledge essential for subjectification: that the mother's desire is, must be, directed elsewhere. The mother-child dyad must be interrupted by a third term, the paternal metaphor, without which no "viable temperate relation of one sex to the other" can exist (Lacan, Four 276).

The heroine then turns to her father :

I say Father.

He turns towards me and it's not my father. It is what my father saw, the thing you meet when you've stayed here too long alone.

I'm not frightened, it's too dangerous for me to be frightened of it; it gazes at me for a time with its yellow eyes, wolf's eyes, depthless but lambent as the eyes of 
animals seen at night in the car headlights. Reflectors. It does not approve of me or disapprove of me, it tells me it has nothing to tell me, only the fact of itself. (243)

It is in response to the narrator's recognition of the paternal metaphor, (the capitalised 'Father') that the imagined figure turns towards the heroine and tells her that from the real, no recognition is possible. This transformed father figure is therefore in his proper role as a mediator, barring all access to the object which is not the mother but the $\mathrm{m}$ (Other), the subject-annihilating beyond of fullness. His wolf-like presence signals this limit: she must go no further. Death, "the fact of itself" is reinstated as a barrier which can only be broached/or breached in the imaginary. A newborn subject, the heroine has learned what she needs to know: that there is no human life outside of culture, outside of language. It is, indeed, a short moment later that the heroine renounces her earlier vow not to teach her child any words, and acknowledges that this is a dead end, an impossibility: "Word furrows potential already in its proto-brain, untravelled paths" (249); she thus recognizes that "For us [humans] it's necessary, the intercession of words" (250). In some sense, the narrator is back where she started: like the rest of us, she is condemned to language.

Yet something has changed. Firstly, the parental prohibition of cruelty and killing has been answered through the affirmation of life: "To prefer life, I owe them that" (245). Secondly, the moment of separation from the symbolic has come to an end, but the protagonist does not return to language unchanged, she is no longer in a state of guilt in relation to the missing part of herself, her objet $a$, and she has given rebirth to her desire, in the form, we shall see, of a fish.

\section{Love}


To be able to go back to the world, one must go back to one's desire and its objects. Copjec points out that "in Freud's account it is the encounter with the gaze of the dead father that enables us to create new meanings" (Copjec 221). ${ }^{18}$ The woman in Surfacing has encountered this gaze twice ${ }^{19}$ : firstly in the murky figure floating under the water when the narrator dives to follow 'clues' left by her father - she sees "a dark oval trailing limbs. It was blurred but it had eyes, they were open, it was something I knew about, a dead thing, it was dead" (182). This inassimilable encounter with the body and gaze of her dead father is the condition and prelude to the wolf-like transformed version of her father, of whom she can now affirm "I knew he wasn't dead" (243). Having encountered the death of her father both in the real and in the imaginary, the signifier of the 'dead father', the phallus, is reinstated, and her desire takes the path of creative sublimation whereby, in the repetitive circling round the object of one's desire, one elevates it to 'the dignity of the Thing', the idealized lost object:

From the lake a fish jumps

An idea of a fish jumps

A fish jumps, carved wooden fish with dots painted on the sides, no, antlered fish thing drawn in red on cliffstone, protecting spirit. It hangs in the air suspended, flesh turned to icon, he has changed again, returned to the water. How many shapes can he take.

I watch it for an hour or so; then it drops and softens, the circles widen, it becomes an ordinary fish again. (243)

We witness here the process of artistic transformation, the loving investment of an object with meaning, and the inexhaustible potential of sublimation. Firstly, according to the Lacanian primacy of the signifier over the signified, the narrating instance gives us a signifier: 'a fish', then transforms it, "fashioning the signifier" (Lacan, Ethics 149 ) into a signified, an 'idea of a fish'; and then, as the fish jumps, and jumps again, circling the air around the empty space from which desire emerges, the potential meanings begin to multiply like the miraculous fish 
in the account of Jesus feeding the thousands.

As Howells points out, this passage condenses many of the images of the fish scattered throughout the novel: "the wooden trophy seen earlier in the village bar, the antlered fish in the copy of the Indian rock paintings, the shadow of the dead father's body" (Howells 31$)^{20}$ As the "he"-fish dynamically surfaces, and "jumps," "jumps," "jumps," from the lake, undergoing creative transfiguration as he "hangs" suspended, we witness "the active gift of love" which defines sublimated jouissance (Copjec 40): "flesh turned to icon," the Jesus-fish offers the woman redemption, which is to say, she is reconciled with the primary signifier, that which stands outside of language, and yet enables it. ${ }^{21}$ Through her act of separation from the group, she has returned to her path of being which owes much to the legacy of her mother, the "Life-saver" (12) who pulled her own drowning son out of the lake (91). The creative resuscitation of the 'dead father'- fish marks the narrator's own symbolic transformation: she is now a life-giver, and has revived her primary signifier and the possibility of renewed desire.

\section{The Quest(ion)}

In this renewed myth of origins, where the heroine finds her way back to her desire, where the superegoic injunction to 'get off' on domination is recused in favour of the poetic joui-sens (pleasure in meaning-making), where does the story end? Will the narrator be able to return to the world of the Other and all its little others, with a language like this? This is the unanswered question at the end of the novel: ${ }^{22}$ as she stands amongst the trees, surrounded by the lake, she hears the voice of Joe who has come back to rescue her from the real, but what he can offer is only the symbolic, the language of the world she has rejected.

Yet there are good reasons to read the novel's ending positively: to begin with, the fish. 
Amongst the numerous references to the aquatic creature, it is twice referred to as a 'goldfish,' a signifier which frames the itinerary of desire lost and rediscovered: at first it is a dull thing; a domesticated, decorative, but finally dispensable object with which Joe is compared:

[Living with Joe] wasn't even a real decision, it was more like buying a goldfish or a potted cactus plant, not because you want one in advance but because you happen to be in the store and you see them lined up on the counter. I'm fond of him, I'd rather have him around than not; though it would be nice if he meant something more to me. (49)

At the novel's close, however, the goldfish gleams with potential, no longer static and doomed, this "shape of a goldfish now in my belly, undergoing its watery changes" is a "time-traveller, the primaeval one," "perhaps the first true human", the one that will escape "the word games, the winning and losing games" (249-50). Fish, child, Joe, and their relation to the renewed and redeemed desire of the heroine are signaled through the now shiny signifier 'gold,' itself but one letter away from the 'god' that she both asserts and renounces in her reaffirmation of the future: "No god and perhaps not real, even that is uncertain; I can't know yet, it's too early. But I assume it [...]; it must be born, allowed" (250). Furthermore, the indeterminacy of the character of Joe is a hopeful sign; constructed as not-fully at one with his position in the symbolic order, he is seen by the heroine "balancing on the dock which is neither land nor water" (186), a mediator. Like the foetus, he is "only half-formed" (251) and therefore, like women, there is something 'not-all', or not entirely bound by the symbolic law, about him. While nothing is certain - "we will probably fail" (251) - Joe's lack of definition distances him from the coercive discourse of the narrator's previous lover. ${ }^{23}$ Whether or not this might make of him a desirable, lovable partner for the protagonist is, however, another question entirely. And finally, through her acts of separation from the symbolic order 
(refusing to kill the fish, detaching herself from her 'friends' in their pursuit of mutual humiliation), the narrator has re-established her autonomy and been restored to the direction of her desire.

The woman's disenchantment with the world is likely to be enduring but she is now in an altered relation to it: reconciled to her structuring lack and to the primary signifier of her desire, the woman has regained her ability to feel, first crying (223) and then laughing ironically at herself (248). Her earlier concern about her "own death" has been succeeded by a new desirousness in relation to the world around her: "everything is alive, everything is waiting to become alive" (203), and she is finally able to affirm, "I am ... alive" (254). Having rejoined the path of her desire, the possibility of living differently with her disillusionment is now open to her through the creative sublimations of art and love, or perhaps, as her vision of the fish suggests, by loving the world artfully. 


\section{Works Cited}

Atwood, Margaret. Dancing Girls, (1977). New York: Anchor Books, 1998.

---. Morning in the Burned House. Toronto: McClelland and Stewart, 1995.

---. Second Words: Selected Critical Prose. Toronto: Anansi, 1982.

---. Surfacing (1972). London: Virago, 1992.

---. Survival: A Thematic Guide to Canadian Literature. Toronto: Anansi, 1972.

Bailly, Lionel. Lacan for Beginners, Oneworld Publications, 2009.

Barry, Peter. Beginning Theory, Manchester: Manchester University Press, $3^{\text {rd }}$ edition, 2009.

Barzilai, Shuli. "Atwood's Quest Romance: A Psychoanalytic Approach to Surfacing" in Approaches to Teaching Atwood's The Handmaid's Tale and Other Works, eds. Thomas Friedman, Shannon Hengen, and Sharon Wilson. New York: Modern Language Association (1996): 161-67.

---. "Who Is He? The Missing Persons Behind the Pronoun in Atwood's Surfacing" in Canadian Literature 164 (2000): 57-79.

Bishop, Elisabeth. "The Fish" in Elizabeth Bishop, The Complete Poems, $1927-$ 1979. New York: Farrar, Straus and Giroux, 1979.

Bouson, J. Brooks. "Chapter 3: Cultural Feminism, Female Madness, and Rage in Surfacing" in Brutal Choreographies: Oppositional Strategies and Narrative Design in the Novels of Margaret Atwood. University of Massachusetts Press, 1993. 39-61.

Braunstein, Nestor. "Desire and Jouissance in the Teachings of Lacan," ed. JeanMichel Rabaté, The Cambridge Companion to Lacan. Cambridge: Cambridge University Press, 2003.

Christ, Carol. Diving Deep and Surfacing: Women Writers on Spiritual Quest. Boston: Beacon, 1980.

Copjec, Joan. Imagine There's No Woman: Ethics and Sublimation, Cambridge: MIT Press, 2004.

Davey, Frank. Reading Canadian Reading. Winnipeg: Turnstone Press, 1988.

Fink, Bruce. A Clinical Introduction to Lacanian Psychoanalysis: Theory and Technique. Cambridge: Harvard University Press, 1997.

---. The Lacanian Subject: Between Language and Jouissance. Princeton: Princeton University Press, 1995.

Hemingway, Ernest. "Hills Like White Elephants" in Men without Women. Charles Scribner's Sons, 1927. 
Howells, Coral Ann. Margaret Atwood, Modern Novelists. London: MacMillan Press, 1996.

Hutcheon, Linda. The Canadian Postmodern. Toronto: Oxford University Press. 1988.

Lacan, Jacques. The Ethics of Psychoanalysis, 1959-1960. Ed. Jacques-Alain Miller, Trans. Dennis Porter. London: Routledge, 1992.

---. The Four Fundamental Concepts of Psycho-Analysis. Ed. Jacques-Alain Miller, Trans. Alan Sheridan. London: Penguin, 1977.

---. On Feminine Sexuality: The Limits of Love and Knowledge, 1972-1973 : Encore, The Seminar of Jacques Lacan, Book XX. Ed. Jacques-Alain Miller. Trans. Bruce Fink. New York: Norton, 1999.

---. "Lituraterre" (1971) in Autres écrits. Paris : Seuil, 2001.

Michaux, Ginette. De Sophocle à Proust, de Nerval à Boulgakov: essai de psychanalyse lacanienne. Ramonville-Saint-Agne: Eres, 2008.

Orwell, George. Coming up for Air, 1939. New York: Penguin, 1980.

Soler, Colette. "Hysteria and Femininity" in What Lacan Said About Women, trans. John Holland. New York: Other Press, 2003.

Woodcock, George. Introducing Margaret Atwood's Surfacing : A Reader's Guide. Toronto: ECW Press, 1990.

Wright, Elizabeth and Edmund, eds. The Zizek Reader. Oxford: Blackwell, 1999.

Zizek, Slavoj. Enjoy Your Symptom: Jacques Lacan in Hollywood and Out. New York: Routledge, 1992.

---. "Love Beyond Law" http://www.lacan.com/zizlola.htm.

---. "Otto Weininger or 'Woman Doesn't Exist"” in Wright: 127-47.

---. Subversions du sujet: psychanalyse, philosophie, politique. Trans. Elisabeth Doisneau. Rennes : Presses Universitaires de Rennes, 1999.

\footnotetext{
1 'Rature' is at once a crossing out and a marking, furrowing, engraving of the letter of language, constitutive of the unconscious.

${ }^{2}$ Characteristic of this perspective is Carol Christ's conclusion to her analysis of the novel: "Atwood's novel suggests that . spiritual insight surfaces through attention to the body; and that the achievement of authentic selfhood and power depends on understanding one's grounding in nature and natural energies" (53).

${ }^{3}$ Complete list: American: 35 references, bear: 18, birch: 8, child: 48, eye: 103, father: 73 , fish: 104, frog: 22 , god: 42 , hand: 146, heron: 17 , human: 27 , lake: 121 , language: 17 , leech: 6 , men 11 , mother: 68 , power 41 , tree: 114 , water: 114 , women: 11 , words: 30 .

${ }^{4}$ The protagonist needs to refer to historical documents to find a meaning that one might attach to
} 
the reactions of her friends. The comparison is excessive, in accordance with the excessive distance she feels from their feelings which "echo" around but do not enter her.

${ }^{5}$ This image will later be echoed in that of the crucified heron's mashed eye (147).

${ }^{6}$ I would agree with Carol Christ's affirmation that the novel constructs a position which "does not suggest that abortion is wrong, but it does suggest that abortion is not a matter of little consequence" (52).

${ }^{7}$ Abortion was de-criminalized in Canada in 1969.

${ }^{8}$ This remark is reminiscent of the rational arguments offered by the American man in Hemingway's "Hills Like White Elephants" to convince 'Jig' to have an abortion: "I know you wouldn't mind it, Jig. It's really not anything. It's just to let the air in."

Jig knows intuitively that it's not 'not anything', at least for her:

"And we could have all this," she said. "And we could have everything and every day we make it more impossible."

"What did you say?"

"I said we could have everything."

"We can have everything."

"No, we can't."

"We can have the whole world."

"No, we can't."

"We can go everywhere."

"No, we can't. It isn't ours any more."

"It's ours."

"No, it isn't. And once they take it away, you never get it back." (357-58).

${ }^{9}$ For a further analysis of images of dismemberment in Surfacing and their suggestiveness of selfmutilation, see Barzilai, "Quest Romance”, 163.

${ }^{10}$ Figured by the symbol $\Phi$ (the Greek letter phi), it is the mark of absolute jouissance, that of the father of the primal horde in the Freudian myth. As such, it is unspeakable, since it must be excluded for subjectivity in the community of speakingbeings to be possible, leaving us all 'castrated' from our mythical fullness, 'reduced' to the status of $-\varphi$ (the negated, small form of $\Phi$ ). As a myth of wholeness, however, it persists, it ex-sists (i.e. insists from outside the boundaries of the possible).

${ }^{11}$ On the question of the fertile indeterminacy and metonymy of the pronoun 'he' in the novel, see Barzilai, "Who Is He?".

${ }^{12}$ Moreover the French name given to the only named lake in the novel is "Lac des Verges Blanches," which means 'White Birch Lake", but could also be translated "Lake of the White Penises/Phalluses"; (the plural use of 'verges' also suggests a whipping stick or scourge).

${ }^{13}$ The term "desirousness" is borrowed from Fink, The Lacanian Subject, 59.

${ }^{14}$ Indeed, Surfacing could be read within the framework of a hysterical discourse in the way that its critical attachment to men is unfailing, and in the extent to which the heroine refuses to be the object of jouissance of her partner, all the while seeking to sustain his desire: the role of the 'other woman', Anna, is equally consistent with this stance. See Soler, 47-67.

${ }^{15}$ This passage also enacts the Lacanian maxim that there is 'no sexual relationship': there is no way in which the two make one, and even the semblance of 'fusion' is negated here in the exchange that follows: '“Is it all right?' he says. He's lying on top of me, breathing, molten, 'Was it all right?' He means two different things; but 'Yes' I say, answer to a third question, unasked" (210). ${ }^{16}$ Occupying victim position 2 on the Atwoodian scale outlined in Survival (36-39), she knows she's a victim, but she doesn't think she can (really, effectively) do anything about it.

${ }^{17}$ From another point of view, the narrator has been 'psychotic' throughout the story, in the sense 
that she "can perfectly well use language in an ordinary manner, but what [s] he lacks is the unconscious background which gives the words we use their libidinal resonance, their specific subjective weight and colour" (Zizek xi). Consider for example the following passage: "I rehearsed emotions, naming them: joy, peace, guilt, release, love and hate, react, relate; what to feel was like what to wear, you watched the others and memorized it" (142).

${ }^{18}$ Moreover, the 'gaze,' as one of the forms of the objet a is not the look in the eye, but the impression that one is being observed: "the gaze marks the place left empty by the death of the father" (Copec, 22). Not the eyes, but the (internalized) place from which you are observed: in Surfacing,the trace of the place left empty by the death of the father is symbolized by the empty footprints in the mud (244), footprints, which logically, turn out to be the protagonists.

${ }^{19}$ Or several times, if we include all the metonymic images of captured, endangered, drowned or gratuitously killed life forms whose eyes meet hers.

${ }^{20}$ Moreover, as the perceiving imagination of the protagonist sees the fish, it takes on the force of its enigmatic symbolism in mythical history, as Christian symbol, as the prized object of the Holy Grail, as the metonym of the phallus in the myth of Osiris. Intertextually, the fish evokes its valiant predecessors, from Melville's Moby Dick and Hemingway's The Old Man and the Sea to Orwell's Coming Up for Air, but, as in Elisabeth Bishop's "The Fish" (42), the narration refuses to posit capture as a desired goal. It is the pleasure in the thing that satisfies.

${ }^{21}$ As the representative of lack, the fish-phallus condenses all the symbolic sites of lack that interest the narrator, pointing towards a myth of origins, a symbol of redemption, a proto-human, a link with the organic, a signifier of indivision, a traveler from the past, a sacrificial victim, and a resistance fighter: the very indeterminacy of the fish links it both to the phallus as primary signifier, and at the same time, the space it describes in circling the air orients us towards the absolute Other as the site of non-meaning, where the signifier meets the limit of the possible and fails to signify.

${ }^{22}$ This is also the question that numerous critics have attempted to resolve: see the summary of debates on the question in Bouson, 59-60.

${ }^{23}$ The question, however, is ongoing: in "The Grave of the Famous Poet," (Dancing Girls) the similarly nameless narrating voice says "We've talked too much or not enough : for what we have to say to each other there's no language, we've tried them all" (83). 